\title{
Additions to the Powdery Mildews of Kerala - II
}

\author{
C.K. Biju ${ }^{1}$, Sony Thomas ${ }^{2}$, S. Sreekumar ${ }^{3}$, and P.N. Krishnan ${ }^{4}$ \\ ${ }^{1,2,3,4}$ Department of Biotechnology and Bioinformatics, Saraswathy Thangavelu Centre of Jawaharlal \\ Nehru Tropical Botanic Garden and Research Institute, Puthenthope, Thiruvananthapuram, India.
}

Abstract: The present paper gives an account of two species of powdery mildew fungi hither to unrecorded
from Kerala. The described species are Pseudoidium clitoriae and Fibroidium balsaminae with their host
range and distribution.
Keywords: Powdery mildews, Kerala, Pseudoidium, Oidium, Fibroidium, Appressoria

\section{Introduction}

Powdery mildews, one of the common plant pathogen forming colonies on the leaves and tender portions of many of the economically important plants. They are distributed in the tropical, subtropical and temperate regions of the world. Owing to the powdery appearance of mycelium and spores on the host surface ascertain the name powdery mildew to these fungi. They are ascomycetous fungi belonging to the family Erysiphaceae under the order Erysiphales. Cutting-edge survey of literature on powdery mildews evidenced that report of powdery mildews from the state of Kerala is negligible. Hence the authors have been exploring the powdery mildews of Kerala and two species hither to unrecorded from Kerala were identified and reported here.

\section{Materials and Methods}

Infected parts, usually leaves and tender portions of the host plants were collected and dried in between blotters without disturbing the colonies. Colony morphology, area of occurrence on the host, colour of the colony and its texture were noted during collection. Mounts were prepared directly from the live specimens or from the dried materials. Fungal morphology including hyphae, appressoria, conidiophores and conidia were studied using standard light microscope. Dimension of the structures were studied using ocular micrometer and micrographs were taken with the camera integrated with the microscope.

\section{Results and Discussion}

Pseudoidium clitoriae (Narayanas. \& K. Ramakr.) U Braun \& R.T.A. Cook Taxonomic manual of the Erysiphales (Powdery mildews) pp. 602-603, 2012

Basionym: Oidium clitoriae Narayanas.\& K. Ramakr. Madras Univ. J. 37-38: 89. (1969)

Colony epiphyllous, white to grey, starts with small spots often following veins, later covering the entire leaf surface, persistent, severe infection often cause curling of leaves; hyphae hyaline to grayish, branched up to $9 \mu \mathrm{m}$ wide; appressoria solitary, nipple shaped to slightly lobed; conidiophores erect, $64-72 \times 9-14$ $\mu \mathrm{m}$; foot-cells cylindrical, straight to slightly flexuous, up to $51 \mu \mathrm{m}$ long, followed by 1-3 cells; conidia produced singly, ovoid, to cylindrical 31-43 x 16-19.5 $\mu \mathrm{m}$.

On leaves of Clitoria ternatea L. (Fabaceae), Saraswathi Thangavelu Centre of JNTBGRI Campus, Near Anakkapillapalam, Puthenthope, Thiruvananthapuram, February 18, 2013, CK. Biju, TBGT 6727.

Narayanaswami \& Ramakrishnan published this fungi [1] from Madras. Subsequently it has been relocated from different parts of Tamil Nadu by various Mycologists [2,3]. It is also reported from Mexico [4]. This species is enlisted in the 'Powdery mildews of India- Check list' [5] and in the monograph 'Indian Erysiphales' [6]. Uwe Braun in his monograph stated that report of this species on Ipomoea obscura (L.) KerGawl (Convolvulaceae) and Stachytarpheta indica L. (Verbinaceae) were not correct and might be based on misidentification and superficial similarities. The anamorph of this species on Cajanus cajan (L.) Millsp. (Fabaceae) is also doubtful according to the monographer [7]. Perusal of the literature evidenced that this fungus is not reported earlier anywhere from Kerala. 


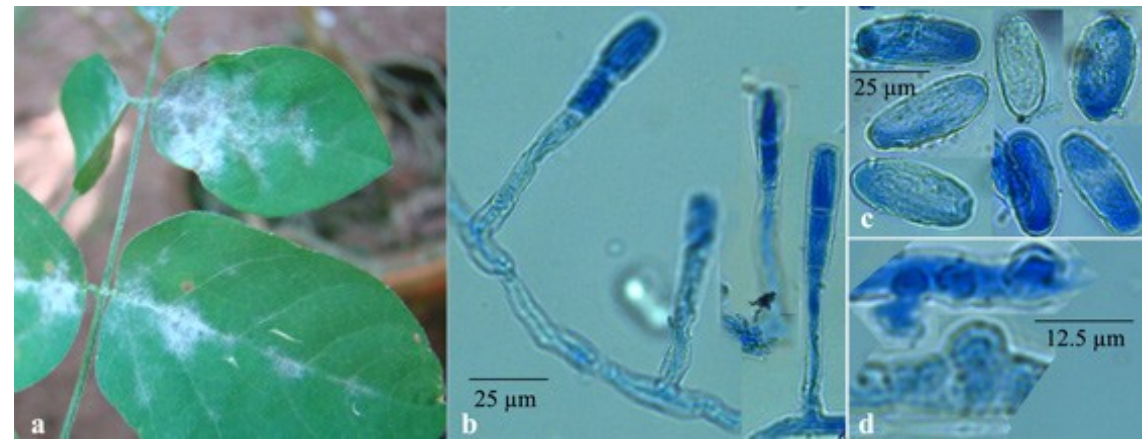

Figure-1 a. infected leaves of Clitoria ternatea, b. hyphae bearing conidiophores, c. conidia and

d. appressoria

Fibroidium balsaminae (Rajd.) U. Braun \& R.T.A. Cook Taxonomic manual of the Erysiphales (Powdery mildews) pp. 167-168, 2012

Basionym: Oidium balsaminae Rajd. Mycopathol. Mycol. Appl. 28: 150, 1966.

$\equiv$ Euoidium balsaminae (Rajd.) Y.S. Paul and J.N. Kapoor, Indian J. Mycol. Pl.

Pathol. 17(3): 302, 1987, nom. inval.

= Sphaerotheca balsaminae auct.p.p.

Colonies epiphyllous, white, thin to dense, effuse, irregular patches often spread on the entire leaf surface; hyphae hyaline, thin-walled, smooth $6-9.7 \mu \mathrm{m}$ wide; appressoria indistinct; conidiophores straight, arising from the hyphal mother cells, $74-117$ x $15 \mu \mathrm{m}$; foot cells cylindrical followed by 1-3 shorter cells producing catenescent conidia; conidia ellipsoid, ovoid to barrel shaped $27-34$ x $13-19.5 \mu \mathrm{m}$ with fibrosin bodies.

On leaves of Impatiens balsamina L. (Balsaminaceae), Saraswathi Thangavelu Centre of JNTBGRI Campus, Near Anakkapillapalam, Puthenthope, Thiruvananthapuram, February 02, 2013, CK. Biju, TBGT 6728

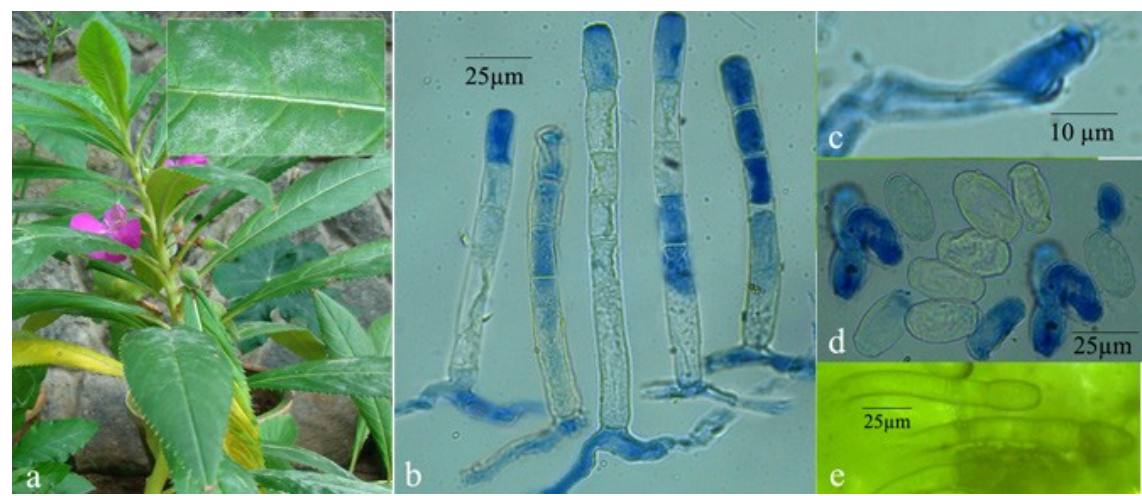

Figure-2 a. infected plant Impatiens balsamina, b. conidiophores, c. appressoria, d. conidia, e. conidiophores on leaf surface

This species was originally published by Rajderkar as Oidium balsaminae on Impatiens balsamina in 1966 [9] from Maharashtra, India and it was reported on various Impatiens spp.(I. capensis, I. chinensis, I. hawkeri, I. textori etc.) from different parts of the world such as Africa, South America, West Indies, Asia (India, China, Japan, Pakistan, Sri Lanka, Thailand, Brunei, Combodia, Israel, Korea, Singapore), Australia and Europe by various taxonomists [7]. From India it was collected from Tamil Nadu by Bappammal, Hosagoudar and Subbarayan [3] from different species of Impatiens, but none of the collections was from Kerala. Thus the present collection forms a new report of the fungi from Kerala.

\section{Conclusion}

Systematic study of powdery mildew fungi in the state of Kerala is very meager, though the conidial or anamorphic stage of these fungi is prevalent on vegetables and other herbal plants in the state. Conidial stages of five taxa of powdery mildews from Thiruvananthapuram district of Kerala state were reported in 2011[10]. A thorough and systematic study of powdery mildews of Kerala is inevitable to reveal the hidden taxa.

\section{Acknowledgement}

We thank the Director, JNTBGRI for providing facilities, Dr. T. Madhan Mohan, Adviser, BITSNET, DBT for support and encouragement and Department of Science and Technology, Govt. of India for financial support. 


\section{Reference}

[1] P. Narayanaswami and K. Ramakrishnan, Powdery mildews of Coimbatore, Madras state, The Madras University Journal, 37-38, 1969, 84-89.

[2] V.B. Hosagoudar, Some powdery mildews from Tamil Nadu, Sydowia, 43, 1991, 23-30.

[3] M. Bappammal, V.B. Hosagoudar, K. Udaiyan, Powdery mildews of Tamil Nadu, India, New Botanist, 22, $1995,81-175$.

[4] N. Ale-Agha, H. Boyle, U. Braun, H. Butin, H. Jage, V. Kummer and H.D. Shin, Taxonomy, host range and distribution of some powdery mildew fungi (Erysiphales), Schlechtendalia, 17, 2008, 39-54.

[5] V.B. Hosagoudar and D.K. Agarwal, Powdery Mildews of India-Check list (Associated publishing company, Karol Bagh, New Delhi, 2009).

[6] Y.S. Paul and V.K. Thakur, Indian Erysiphaceae (Scientific Publishers India, Jodhpur, 2006).

[7] U. Braun and R.T.A. Cook, Taxonomic manual of the Erysiphales (Powdery mildews) CBS Biodiversity Series II (CBS-KHAW Fungal Biodiversity Centre, Utrecht, The Netherlands, 2012).

[8] N. Ahmed, D.K. Agarwal, O.M. Bambawal and K.C. Puzari, Erysiphaceae of India Monographic treatment (New Delhi 2007).

[9] N.R. Rajderkar, Occurrence of two powdery mildews on Balsam, Impatiens balsamina L., Mycopathologia et. Mycologia Applicata $28(1-2), 1966,149-152$.

[10] C.K. Biju, V.B. Hosagoudar and S. Sreekumar, Additions to the Powdery mildews of Kerala, India, Bioscience discovery 2(1), $2011,38-42$. 